\title{
Solute Carrier Family 22 Member 1
}

National Cancer Institute

\section{Source}

National Cancer Institute. Solute Carrier Family 22 Member 1. NCI Thesaurus. Code C105075.

Solute carrier family 22 member $1(554 \mathrm{aa}, \sim 61 \mathrm{kDa})$ is encoded by the human SLC22A1 gene. This protein is involved in bidirectional cation transport. 